\title{
PENDIDIKAN DAN KEBIJAKAN POLITIK (KAJIAN REFORMASI PENDIDIKAN DI INDONESIA MASA ORDE LAMA HINGGA REFORMASI)
}

\begin{abstract}
Yudi Hartono*
Abstrak

Pendidikan dan politik memiliki hubungan yang dinamis. Pendidikan dan politik berhubungan erat dan saling memengaruhi. Berbagai aspek pendidikan senantiasa mengandung unsur-unsur politik, begitu juga sebaliknya, setiap aktivitas politik ada kaitannya dengan aspek-aspek kependidikan. Pada masa awal kemerdekaan, kebijakan pendidikan pada masa Orde Lama ditujukan pada pendidikan sosialisme Indonesia. Kebijakan pendidikan pada masa Orde Baru diarahkan pada penyeragaman di dalam berpikir dan bertindak. Pendidikan di era reformasi 1999 mengubah wajah sistem pendidikan Indonesia melalui UU No 22 tahun 1999, dengan ini pendidikan menjadi sektor pembangunan yang didesentralisasikan. Untuk dapat memahami berbagai persoalan pendidikan yang ada di tengah masyarakat tidak hanya diperlukan dasar pengalaman dan pengetahuan pendidikan, tetapi juga diperlukan pengetahuan tentang aspek-aspek dan konteks politik dari persoalan-persoalan kependidikan tersebut.
\end{abstract}

\section{Kata Kunci: Pendidikan, Kebijakan Politik, Orde Lama, Reformasi}

\section{Pendahuluan}

Pendidikan dan politik memiliki hubungan yang dinamis. Pendidikan dan politik berhubungan erat dan saling memengaruhi. Berbagai aspek pendidikan senantiasa mengandung unsur-unsur politik, begitu juga sebaliknya, setiap aktivitas politik ada kaitannya dengan aspek-aspek kependidikan. Namun demikian, tidak semua pihak mengakui dan mendukung hubungan atau keterkaitan antara politik dan pendidikan. Banyak pihak yang resah dengan realitas tersebut dan menginginkan upaya-upaya perubahan untuk meminimalisasi atau mengikis elemenelemen politik dalam dunia pendidikan. Mereka menginginkan agar pendidikan dan politik menjadi dua wilayah yang terpisah. Mereka percaya bahwa pemisahan antara politik dan pendidikan dapat dilakukan untuk membebaskan lembaga-lembaga pendidikan dari berbagai kepentingan politik penguasa.

Menurut Harman (dalam M. Sirozi, 2010: 25), pandangan bahwa pendidikan dan politik merupakan dua hal yang sama sekali terpisah tidak mengandung kebenaran, baik di negara-negara industri seperti di Amerika dan Australia maupun di negara-negara berkembang. Ia percaya bahwa di belahan dunia manapun, politik dan pendidikan saling terkait dan saling memengaruhi. Keduanya adalah dua aktivitas yang mendasar dalam semua masyarakat manusia.

Pendidikan menyangkut proses transmisi ilmu pengetahuan dan budaya, serta perkembangan keterampilan dan pelatihan untuk tenaga kerja. Politik berkenaan dengan praktik kekuasaan, pengaruh dan otoritas, serta pembuatan keputusan-keputusan otoritatif tentang alokasi nilai-nilai dan sumberdaya. Karena keduanya sarat dengan proses pengalokasian dan pendistribusian nilainilai dalam masyarakat, maka tidaklah sulit untuk memahami bahwa pendidikan dan politik adalah dua aktivitas yang akan terus terkait dan saling berinteraksi. Lembagalembaga yang menyelenggarakan aktivitasaktivitas pada dua sektor kehidupan masyarakat ini akan saling memengaruhi, apapun karakteristik dan budaya yang dimiliki oleh suatu masyarakat. Hal ini terjadi dalam setiap masyarakat, apapun 
tingkat perkembangannya, sistem politiknya dan ideologinya.

Untuk dapat memahami berbagai persoalan pendidikan yang ada di tengah masyarakat tidak hanya diperlukan dasar pengalaman dan pengetahuan pendidikan, tetapi juga diperlukan pengetahuan tentang aspek-aspek dan konteks politik dari persoalan-persoalan kependidikan tersebut.

\section{Perspektif Historis}

Di negara-negara Barat, kajian antara hubungan pendidikan dan politik dimulai oleh Plato dalam bukunya Republic. Walaupun kajian utamanya membahas berbagai persoalan kenegaraan, buku tersebut juga membahas hubungan antara ideologi dan institusi negara dengan tujuan dan metode pendidikan. Menurut Plato, para filsuf memiliki otoritas tertinggi, para pengawas berpendidikan menengah bertindak sebagai kekuatan militer dan polisi, dan mereka yang memasok kebutuhan ekonomi negara menempatkan status terendah diantara semuanya. Pendidikan harus disesuaikan secara cermat dengan reproduksi sistem; kelas yang lebih rendah dididik untuk patuh dan diyakinkan dengan mitos-mitos politik bahwa status mereka itu terbentuk oleh sebab-sebab alamiah; para penyair seharusnya hanya menggambarkan tingkahlaku terpuji, pengetahuan tentang bentuk-bentuk masyarakat alternatif ditekan dengan hatihati, kecuali dalam kalangan sangat terbatas dari elit penguasa (Kuper \& Kuper, 2000: 767).

Plato mendemonstrasikan dalam buku tersebut bahwa sekolah adalah salah satu aspek kehidupan yang terkait dengan lembaga-lembaga politik. Ia menjelaskan bahwa setiap budaya mempertahankan kontrol atas pendidikan di atas kelompokkelompok elit yang secara terus menerus menguasai kekuasaan politik, ekonomi, agama dan pendidikan. Plato menggambarkan adanya hubungan dinamis antara aktivitas kependidikan dan aktivitas politik. Keduanya seakan dua sisi dari satu koin, tidak mungkin terpisahkan. Walaupun sangat umum dan singkat, analisis Plato tersebut telah meletakkan fundamental bagi kajian hubungan politik dan pendidikan..

Di dunia Islam, menurut M. Sirozi (2010: 1) gambaran tentang keterkaitan antara pendidikan dan politik ditandai oleh kesungguhan para ulama dan umara dalam memperhatikan persoalan pendidikan sebagai upaya untuk memperkuat posisi sosial politik kelompok dan pengikutnya. Lebih lanjut M. Sirozi mengutip analisis dari Abdurrasyid (1994) tentang pendidikan pada masa Islam klasik dengan hasil kesimpulan dalam sejarah perkembangan Islam, institusi politik ikut mewarnai corak pendidikan yang dikembangkan. Keterlibatan para penguasa dalam kegiatan pendidikan waktu itu, menurut Rasyid, tidak hanya sebatas dukungan moral kepada para peserta didik, melainkan juga dalam bidang administrasi, keuangan dan kurikulum (1994: 3). Dia menulis sebagai berikut.

"Tidak dapat dipungkiri bahwa lembaga pendidikan merupakan salah satu konstalasi politik. Peranan yang dimainkan oleh masjid-masjid dan madrasah-madrasah dalam mengokohkan kekusaan politik para penguasa dapat dilihat dalam sejarah. Di lain pihak, ketergantungan pada uluran tangan para penguasa secara eonomis, membuat lembaga-lembaga tersebut harus sejalan dengan nuansa politik yang berlaku." (Rasyid, 1994: 6).

Di antara lembaga pendidikan Islam yang menjadi corong pesan-pesan politik, menurut Rasyid (1994: 6), adalah madrasah Nizhamiyah di Baghdad. Dia menyimpulkan dari analisis terhadap kasus madrasah Nizhamiyah sebagai berikut.

"Kedudukan politik di dalam Islam sama pentingnya dengan pendidikan. Tanpa otoritas politik, syari'at Islam sulit bahkan mustahil untuk ditegakkan. Kekuasaan adalah sarana untuk mempertahankan syiar Islam... Pendidikan bergerak dalam usaha menyadarkan umat untuk menjalankan syari'at. Umat tidak akan mengerti syari'at tanpa adanya pendidikan. Bila politik (kekuasaan) mengayomi dari atas, maka pendidikan melakukan pembenahan lewat arus bawah." (Rasyid, 1994: 15).

Kutipan di atas menegaskan bahwa hubungan antara politik dan pendidikan di 
dalam Islam tampak sedemikian erat. Perkembangan kegiatan-kegiatan kependidikan banyak dipengaruhi oleh para penguasa dan para penguasa memerlukan dukungan institusi-institusi pendidikan untuk membenarkan dan mempertahankan kekuasaan mereka. Hal ini dapat dipahami, karena tujuan pemerintahan Islam, Menurut Abdul Ghaffar Aziz (1993: 95) dalam M. Sirozi (2010: 3), adalah "menegakkan kebenaran dan keadilan. Tujuan itu tidak mungkin tercapai kecuali dengan melaksanakan syari'at. Syari'at tidak akan berjalan bila umat tidak memahami ajaran Islam".

Menurut M. Sirozi (2010: 4), selain karena faktor religius bahwa agama Islam sangat menjunjung aktivitas kependidikan, perhatian besar para pemimpin Islam terhadap masalah pendidikan didorong oleh besarnya peran lembaga-lembaga pendidikan dalam penyampaian misi-misi politik. Pendidikan sering dijadikan media dan wadah untuk menanamkan ideologi negara atau tulang yang menopang kerangka politik.

Di Indonesia pada masa awal kemerdekaan, kaum nasionalis dapat menguasai birokrasi dan sektor-sektor strategis. Kebijakan pendidikan pada masa Orde Lama sesuai dengan tujuan negara, yaitu pendidikan sosialisme Indonesia oleh pemerintahan Ir. Soekarno (1961-1966). Menteri pendidikan pertama Ki Hajar Dewantara beberapa bulan sesudah proklamasi kemerdekaan mengeluarkan Instruksi Umum, yang isinya menyerukan kepada para pengurus upaya membuang sistem pendidikan kolonial dan mengutamakan patriotisme. Sosialisme Indonesia yang dijalankan oleh pemerintah, di tingkatan kebijakan, sampai penerapannya dilingkungan pendidikan formal, SMP, SMA, dan perguruan tinggi, merupakan salah satu cara mensejalankan tujuan pendidikan dengan tujuan negara. Pemerintah membuat suatu kurikulum yang sesuai dengan tujuan tersebut, dan lahirlah mata pelajaran Ilmu Kewargaan Negara atau Civics, yang diajarkan di tingkat SMP dan SMA.
Indonesia di era Orde Lama merupakan negara yang sarat dengan citacita sosialisme. Cita-cita sosialisme ini termasuk juga dalam bidang pendidikan. Statuta Universitas Gadjah Mada (UGM) tahun 1951 sangat tegas menyatakan bahwa tujuan UGM adalah menyokong sosialisme pendidikan. Namun pada tahun 1992, di bawah kekuasaan Orde Baru, statuta ini diganti dengan banyak perubahan pada isinya satu perubahannya adalah menghilangkan pasal mengenai tujuan menyokong sosialisme pendidikan Indonesia. Kebijakan pendidikan saat itu dilakukan secara sentralistik, sebagaimana dijelaskan oleh Tilaar (2000:2) bahwa kebijakan pendidikan di masa ini diarahkan kepada proses indoktrinasi dan menolak segala unsur budaya yang datangnya dari luar.

Semangat diskriminatif di dalam sekolah formal mulai dikikis. Anak-anak dari kalangan buruh dan tani mulai bisa menikmati dan mengenyam bangku pendidikan. Secara yuridis, pemikiran tentang pendidikan nasional dapat dilacak dalam Undang-Undang Nomor 4 Tahun 1950 tentang Dasar-Dasar Pendidikan dan Pengajaran di Sekolah (Lembaran Negara Tahun 1950 Nomor 550), yang pelaksanaannya ditegaskan dalam UU No.12 Tahun 1954, tentang pernyataan berlakunya UU No.4 Tahun 1950 tentang Dasar-Dasar Pendidikan dan Pengajaran di Sekolah Untuk Seluruh Indonesia (lembaran Negara Tahun 1954 Nomor 38. Tambahan lembaran Negara Nomor 550). Tujuan dan dasar pendidikan pada Orde Lama dapat dilihat pada pasal 3 dan 4. Pasal 3:" Tujuan pendidikan dan pengajaran adalah membentuk manusia susila yang cakap dan warga Negara yang demokratis serta bertanggungjawab tentang kesejahteraan masyarakatdan tanah air "Pasal 4: "Pendidikan dan pengajaran berdasar atas asas-asas yang termaktub dalam Pancasila, UUD Negara Republik Indonesia dan atas kebudayaan kebangsaan Indonesia". Konsep pendidikan ini akhirnya berakhir ketika pada tahun 1965.

Orde Baru memilih perbaikan dan perkembangan ekonomi sebagai tujuan 
utamanya dan menempuh kebijakannya melalui struktur administratif yang didominasi militer namun dengan nasehat dari ahli ekonomi didikan Barat. Orde baru berlangsung dari tahun 1968 hingga 1998, dan dapat dikatakan sebagai era pembangunan nasional. Pendidikan orde baru mengusung ideologi "keseragaman" sehingga memampatkan kemajuan dalam bidang pendidikan. EBTANAS, UMPTN, menjadi seleksi penyeragaman intelektualitas peserta didik. Selain itu, masa ini juga diwarnai dengan ideologi militeralistik dalam pendidikan yang bertujuan untuk melanggengkan status quo penguasa. Pendidikan militeralistik diperkuat dengan kebijakan pemerintah dalam penyiapan calon-calon tenaga guru negeri.

Pemerintahan Orde Baru yang dipimpin Soeharto mengedepankan moto "membangun manusia Indonesia seutuhnya dan masyarakat Indonesia". Pada tahun 1969-1970 diadakan Proyek Penilaian Nasional Pendidikan (PPNP) dan menemukan empat masalah pokok dalam pendidikan di Indonesia: pemerataan, mutu, relevansi, dan efisiensi pendidikan. Dan hasilnya digunakan untuk membentuk Badan Penelitian dan Pengembangan Pendidikan dan Kebudayaan (BP3K). Depdiknas di bawah Menteri Wardiman Djojohadiningrat (kabinet pembangunan VI) mengedepankan wacana pendidikan "link and match" sebagai upaya untuk memperbaiki pendidikan Indonesia pada masa itu (Rianti Nugroho, 2008: 16).

Sebagaimana sistem politik yang ada pada era ini, maka manajemen pendidikan dilaksanakan secara sentralistis. Semua kebijakan sampai detail ditentukan oleh pusat. Sekolah sebagai lembaga yang langsung melaksanakan proses pembelajaran tidak memiliki kewenangan yang memadai. Kebijakan ini memiliki implikasi perencanaan dan upaya peningkatan mutu bersifat top-down. Akibatnya, peningkatan mutu tidak ada di sekolah-sekolah, dan hanya ada di pusat.

Kebijakan pendidikan pada masa Orde Baru diarahkan pada penyeragaman. Tilaar (2002:3) menjelaskan pendidikan di masa ini diarahkan kepada uniformalitas atau keseragaman di dalam berpikir dan bertindak. Pakaian seragam, wadah-wadah tunggal dari organisasi sosial masyarakat, semuanya diarahkan kepada terbentuknya masyarakat yang homogen. Pada masa ini tidak ada tempat bagi perbedaan pendapat, sehingga melahirkan disiplin semu dan melahirkan masyarakat peniru. Pada masa ini pertumbuhan ekonomi yang dijadikan panglima.

Relevansi Pendidikan diperhatikan dengan penyesuaian isi pendidikan dengan kebutuhan pembangunan terhadap sumber daya manusia yang diperlukan. Kebijakan ini secara eksplisit muncul pada pelita I, II, III, I dan V. Setelah perluasan kesempatan belajar, sasaran perbaikan bidang pendidikan selanjutnya adalah pemberantasan buta aksara. Kenyataan bahwa masih banyak penduduk yang buta huruf ditanggapi pemerintahan Soeharto dengan pencanangan penuntasan buta huruf pada 16 Agustus 1978. Tekniknya adalah dengan pembentukan kelompok belajar atau "kejar".

Dengan mencanangkan "wajib belajar 9 tahun", termasuk juga yang tak kalah populer adalah dibukanya program SD Inpres untuk daerah-daerah terpencil dan terisolir di berbagai belahan daerah di Indonesia. Program wajib belajar dicanangkan pada 2 Mei 1984.

Bank Dunia pada tahun-tahun akhir 1970-an dan awal tahun 1980-an memberikan resep untuk meningkatkan efektivitas pendidikan guru dengan merombak kurikulum IKIP yang semula mirip kurikulum Universitas menjadi khas IKIP, dimana kurikulum baru ini terlalu berlebih-lebihan menekankan pembelajaran dan mengurangi secara besar-besaran materi bidang studi. Para pedagog yang tidak sefaham dengan resep ini dengan sinis mengatakan bahwa "di kurikulum IKIP yang baru ini, "bagaimana cara memegang kapur pun diajarkan". Mutu guru lulusan IKIP merosot tajam. Guru menguasai berbagai pendekatan dan metodologi mengajar, tetapi tidak menguasai apa yang harus diajarkan.Kebijakan ke dua dalam peningkatan mutu pendidikan adalah 
dengan meningkatkan kualitas guru lewat projek peningkatan mutu guru yang dilakukan dengan model pelatihan guru yang sangat terencana mulai dari teori, praktik sampai on the job training di sekolah-sekolah masing-masing.

\section{Pendidikan dan Kebijakan Politik Masa Reformasi}

Era reformasi memberi ruang yang cukup besar bagi perumusan kebijakan pendidikan baru yang bersifat reformatif dan revolusioner. Bentuk kurikulum menjadi berbasis kompetensi. Begitu pula bentuk pelaksanaan pendidikan berubah dari sentralistik menjadi desentralistik. Pada masa ini pemerintah menjalankan amanat UUD 1945 dengan memprioritaskan anggaran pendidikan sekurang-kurangnya $20 \%$ dari anggaran pendapatan belanja negara.

Dengan didasarkan oleh UU No. 22 tahun 1999 tentang pemerintahan daerah, yang diperkuat dengan UU No. 25 tahun 1999 tentang perimbangan keuangan pusat dan daerah, maka pendidikan digiring pada pengembangan lokalitas, di mana keberagaman sangat diperhatikan. Masyarakat dapat berperan aktif dalam pelaksanaan satuan pendidikan.

Pendidikan di era reformasi 1999 mengubah wajah sistem pendidikan Indonesia melalui UU No 22 tahun 1999, dengan ini pendidikan menjadi sektor pembangunan yang didesentralisasikan. Pemerintah memperkenalkan model "Manajemen Berbasis Sekolah". Sementara untuk mengimbangi kebutuhan akan sumber daya manusia yang berkualitas, maka dibuat sistem "Kurikulum Berbasis Kompetensi".

Memasuki tahun 2003 pemerintah membuat UU No.20 tahun 2003 tentang sistem pendidikan nasional menggantikan UU No 2 tahun 1989, dan sejak saat itu pendidikan dipahami sebagai, "Usaha sadar dan terencana untuk mewujudkan suasana belajar dan proses pembelajaran agar peserta didik secara aktif mengembangkan potensi dirinya untuk memiliki kekuatan spiritual keagamaan, pengendalian diri, kepribadian, kecerdasan, akhlak mulia, serta keterampilan yang diperlukan dirinya, masyarakat, bangsa dan Negara." (Standar Nasional Pendidikan, 2005:102).

Anggaran pendidikan ditetapkan sesuai dengan UUD 1945 yaitu 20\% dari APBN dan APBD, sehingga banyak terjadi reformasi di dunia pendidikan, terutama dalam dalam pemberian dana Bantuan Operasional Sekolah (BOS), Wajib Belajar 9 tahun, dan peningkatan standar penghasilan Guru dengan adanya sertifikasi guru, serta pemberian bantuan pendidikan (Beasiswa) untuk peningkatan kompetensi guru, dan sebaginya.

Pasal 39 Ayat (2) Undang-Undang Nomor 20 tahun 2003 tentang sistem pendidikan nasional bahwa pendidik merupakan tenaga profesional. Kedudukan guru dan dosen sebagai tenaga profesional mempunyai visi terwujudnya penyelenggaraan pembelajaran sesuai dengan prinsip-prinsip profesionalitas untuk memenuhi hak yang sama bagi setiap warga negara dalam memperoleh pendidikan yang bermutu.

Undang-undang nomor 14 tahun 2005 tentang guru dan dosen Pasal 2 ayat (1) Guru sebagai tenaga profesional mengandung arti bahwa pekerjaan guru hanya dapat dilakukan oleh seseorang yang memiliki kualifikasi akademik, kompetensi, dan sertifikat pendidik sesuai dengan persyaratan untuk setiap jenis dan jenjang pendidikan tertentu. Pasal (4) Yang dimaksud dengan guru sebagai agen pembelajaran (learning agent) adalah peran guru antara lain sebagai fasilitator, motivator, pemacu, perekayasa pembelajaran, dan pemberi inspirasi belajar bagi peserta didik.

\section{Format Hubungan}

Hubungan antara politik dan pendidikan terwujud ke dalam berbagai bentuk yang berbeda-beda, sesuai karakteristik setting sosial politik dimana hubungan itu terjadi. Bentuk hubungan tersebut berbeda-beda dari satu masyarakat ke masyarakat lainnya. Dalam suatu masyarakat, hubungan tersebut bisa saja sangat kuat dan riil dan dalam masyarakat 
lainnya hubungan tersebut bisa saja lemah dan tidak nyata. Pola hubungan antara pendidikan dan politik di negara-negara berkembang berbeda-beda dari satu masyarakat ke masyarakat lainnya. Dalam masyarakat yang lebih primitif yang berdasarkan pada basis kesukuan (Tribalbased societies) misalnya, lazim bagi orang tua dari satu suku memainkan dua peran, sebagai pemimpin politik dan sebagai pendidik. Mereka membuat keputusankeputusan penting dan memastikan bahwa keputusan-keputusan ini diimplementasikan dan diterapkan. Mereka juga mempersiapkan generasi muda untuk memasuki kehidupan dewasa dengan mengajarkan mereka teknik-teknik berburu dan mencari ikan, metode-metode berperang dan sebagainya. Selain itu, mereka juga menanamkan pada generasi muda mereka kepercayaan, nilai-nilai dan tradisi serta mempersiapkan mereka untuk berperan secara politis.

Dalam masyarakat yang lebih maju dan berorientasi teknologi, serta mengadopsi nilai-nilai dan lembaga-lembaga Barat, pola hubungan antara pendidikan dan politik berubah dari pola tradisional kepada pola modern. Di banyak negara berkembang, dimana pengaruh modernisasi sangat kuat, pola hubungan pendidikan dan politik umumnya sama dengan hubungan pendidikan dan politik di negara-negara Barat. Ada satu perbedaan bahwa di negaranegara berkembang yang lebih maju, pendidikan formal memainkan peran yang sangat penting dan nyata dalam mencapai perubahan politik, dan dalam proses rekrutmen dan pelatihan pemimpin dan elite politik baru. Di sebagian negara maju, pendidikan berada dalam arus utama kehidupan politik nasional dan menjadi isu penting dalam wacana politik. Di negaranegara lain, persoalan kebijakan pendidikan kurang mendapat perhatian dan bukan merupakan topik yang hangat sebagai wacana publik.

Dalam masyarakat modern pada umumnya, pendidikan adalah komoditi politik yang sangat penting. Proses dan lembaga-lembaga pendidikan memiliki aspek dan wajah politik yang banyak, serta memiliki beberapa fungsi penting yang berdampak pada sistem politik, stabilitas dan praktik sehari-harinya. Dalam masyarakat modern pendidikan merupakan wilayah tanggung jawab pemerintah yang besar. Pendidikan publik bersifat politis karena dikontrol oleh pemerintah dan memengaruhi kredibilitas pemerintah. Karena besarnya nuansa politik dari kebijakan-kebijakan pendidikan, maka berbagai faktor politis yang tidak ada hubungannya dengan pendidikan turut memengaruhi bagaimana kontrol terhadap pendidikan dan bagaimana kebijakankebijakan pendidikan dibuat. Sebagai wilayah tanggung jawab pemerintah, pendidikan sering "dipaksa" menyesuaikan diri dengan pola-pola administratif umum dan norma-norma yang berlaku. Akibatnya, pendidikan publik dibiayai dan dikontrol oleh pemerintah sama halnya pemerintah membiayai dan mengontrol bidang-bidang lainnya, seperti pertanian, kesehatan, atau pelayanan sosial.

Karena kuatnya kaitan antara masalah pendidikan dan politik serta aspek-aspek publik lainnya, setiap kebijakan pemerintah di bidang pendidikan pada umumnya merefleksikan pandangannya tentang masyarakat dan keyakinan politiknya. Masing-masing pemerintah menempatkan prioritas pendidikan yang berbeda-beda, dan menyukai kebijakan-kebijakan yang merefleksikan pandangan dasar dan kepentingan-kepentingan mereka. Dari waktu ke waktu pemerintah membuat kebijakan-kebijakan pendidikan atas dasar pertimbangan-pertimbangan politik. Keputusan-keputusan tentang pendidikan sering dipengaruhi oleh faktor-faktor keuangan yang dihadapi oleh pemerintah. Sekolah-sekolah, universitas-universitas dan lembaga pendidikan negeri merupakan sektor publik yang paling terpengaruh oleh penerapan sistem politik. Ini tidak berarti bahwa lembaga-lembaga pendidikan non pemerintah tidak terpengaruh oleh keputusan-keputusan dan kontrol pemerintah. Karena pada umumnya sekolahsekolah non pemerintah sangat tergantung pada subsidi negara, maka untuk mendapatkan subsidi pemerintah, sekolah- 
sekolah non pemerintah tersebut seringkali diharuskan oleh pemegang otoritas pendidikan untuk memenuhi persyaratan yang ditetapkan oleh pemerintah, seperti menyesuaikan struktur organisasi sekolah, merombak kurikulum, kriteria pengangkatan guru, prosedur pengelolaan dana, format akreditasi, tidak memasukkan bidang studi tertentu, tidak menggunakan buku pelajaran tertentu, menggunakan seragam tertentu, melaksanakan upacaraupacara tertentu dan sebagainya.

Sekolah-sekolah non pemerintah yang sangat tergantung pada izin dan subsidi pemerintah tidak punya banyak pilihan selain mengikuti persyaratan yang ditetapkan oleh pemerintah, walaupun dengan begitu tidak sedikit dari sekolahsekolah tersebut harus "kehilangan identitas" atau terpaksa "lari" dari visi, misi, dan tujuan awal pendiriannya. Di banyak negara, terutama di negara-negara berkembang, sangat sedikit sekolah non pemerintah yang dapat meloloskan diri dari "jerat" politik pendidikan penguasa. Di Indonesia, Pondok Modern Gontor yang tidak mau mengikuti berbagai persyaratan yang dituntut oleh otoritas pendidikan di negeri ini. Hasilnya sangat jelas; sementara banyak sekolah-sekolah dan pondok pesantren non pemerintah "kehilangan identitas" dan terjebak ke dalam uniformitas pendidikan yang diterapkan oleh otoritas pendidikan di tanah air. Selain itu, Pondok Modern Gontor adalah salah satu dari sedikit institusi pendidikan di tanah air yang mendapat pengakuan international. Banyak lulusan Pondok Modern Gontor yang diterima di Al-Azhar, Mesir, dengan kewajiban mengikuti program matrikulasi yang sangat minim.

Jika politik dipahami sebagai "praktik kekuatan, kekuasaan dan otoritas dalam masyarakat, serta pembuatan keputusankeputusan otoritas tentang alokasi sumber daya dan nilai-nilai sosial" (Harman, 1974: 9), maka jelaslah bahwa pendidikan tidak lain adalah sebuah bisnis politik. Semua lembaga pendidikan, baik pemerintah maupun non pemerintah, dalam batas-batas tertentu tidak terlepas dari bisnis pembuatan keputusan-keputusan yang disertai otoritas dan yang dapat diberlakukan. Lembaga-lembaga pendidikan tersebut terlibat dalam praktik kekuatan, kekuasaan dan otoritas. Dengan kata lain, politik adalah bagian dari paket kehidupan lembaga-lembaga pendidikan. Bahkan menurut Baldridge (1971), lembagalembaga pendidikan dipandang sebagai sistem-sistem politik-mikro, yang melaksanakan semua fungsi utama sistemsistem politik. Tentu saja aktivitas politik di sebuah sekolah dasar yang kecil dalam banyak hal kurang penting dibandingkan dengan sistem politik di Kementrian Pendidikan. Namun, pada hakikatnya aktivitas politik pada dua lembaga pendidikan tersebut sama saja jenisnya. Sebuah keputusan yang dibuat dalam rapat guru-guru sekolah untuk mengimplementasikan sebuah program pengajaran baru sama politisnya dengan sebuah keputusan yang dibuat oleh Kementrian Pendidikan dalam rangka mengalokasikan sejumlah dana bantuan untuk sekolah-sekolah tertentu.

Hal ini menegaskan bahwa pendidikan dan politik adalah dua hal yang berhubungan erat dan saling memengaruhi. Dengan kata lain, berbagai aspek pendidikan senantiasa mengandung unsur-unsur politik, begitu juga sebaliknya, setiap aktifitas politik ada kaitannya dengan aspek-aspek kependidikan. Pendidikan pada masa reformasi tidak saja berkaitan dengan kekuasaan politik di tingkat nasional, tetapi juga di tingkat lokal.

\section{Ide Non-Political School}

Meskipun hubungan atau keterkaitan antara politik dan pendidikan begitu kuat dan riil, tidak semua orang mengakui dan mendukung realitas tersebut. Banyak pihak yang resah dengan realitas tersebut dan menginginkan upaya-upaya perubahan untuk meminimalisasi atau mengikis elemen-elemen politik dalam dunia pendidikan. Mereka menginginkan agar pendidikan dan politik menjadi dua wilayah yang terpisah dan tidak berhubungan. Mereka percaya bahwa pemisahan antara politik dan pendidikan dapat dilakukan 
untuk membebaskan lembaga-lembaga pendidikan dari berbagai kepentingan politik penguasa. Kecenderungan tersebut memuncak pada tahun 1970-an, khususnya di Amerika Serikat (Harman, 1974: ii).

Pada waktu itu ada keinginan untuk menciptakan dinding pemisah antara karakteristik sebuah sistem politik dengan kebijakan pendidikan. Kecenderungan itu berkaitan erat dengan ideologi dan praktikpraktik politik. Di berbagai negara, ada beberapa ilmuwan pendidikan dan politik yang mengabaikan aspek-aspek politik dari pendidikan dan berpendapat bahwa pendidikan dan politik perlu dipisahkan. Pandangan ini biasanya berangkat dari kekecewaan yang mendalam terhadap berbaga realitas politik, seperti praktikpraktik korupsi yang dilakukan oleh partaipartai politik pada akhir abad ke-19. Namun, karena minimnya kajian tentang persoalan ini, penjelasan tentang dasar-dasar pemisahan antara pendidikan dan politik di berbagai negara masih sulit ditemukan.

Apapun latar belakang dan tujuan kemunculannya, kecenderungan pemisahan dan pengintegrasian pendidikan dan politik merupakan persoalan penting yang perlu dicermati, baik oleh ilmuwan pendidikan maupun ilmuwan politik. Pemahaman terhadap karakteristik hubungan antara pendidikan dan politik adalah suatu prasyarat yang diperlukan untuk dapat memahami politik pendidikan sebagai suatu bidang kajian akademik dan beberapa mitos yang mengitarinya. Hingga tahun 1980-an, menurut catatan Harman (1974:3), dibanyak negara masih ada keyakinan yang meluas bahwa pendidikan dan politik adalah aktivitas yang terpisah dan tidak memiliki kaitan apa-apa. Para pemilik keyakinan ini bersikukuh bahwa pendidikan memang seharusnya terpisah dari politik. Keyakinan seperti ini telah mengaburkan pengertian the politics of education atau politik pendidikan dan tujuan, fokus, serta wilayah kajian politik pendidikan sebagai sebuah kaijan bidang akademik. Di Amerika, Harma (1974: 3) memberi contoh, keyakinan bahwa pendidikan dan politik adalah dua hal yang terpisah dan tidak memiliki hubungan apapun juga sangat kuat. Selama bertahun- tahun sekolah-sekolah publik (public schools) di negara tersebut ditempatkan dalam sebuah atmospher anti-political dan non-political.

Ide tentang non-political school di Amerika mula-mula dikembangkan dan disebarluaskan oleh para administratur sekolah dan para pendidik profesional yang ingin melindungi pendidikan publik dari politik lokal dan nasional Amerika awal abad ke-19 yang berwatak korup dan kejam. Salah satu pionir pandangan ini, Thomas $\mathrm{H}$. Eliot (1959), menjelaskan logika pandangannya, bahwa semua sistem sekolah telah "dirusak oleh berbagai aspek politk yang masuk secara paksa, khususnya penggunaan patronase dalam pengangkatan (staf) dan penentuan kontrak-kontrak (kerja) dengan mengabaikan kemungkinan pendidikan yang terbaik bagi anak-anak". Menurut Bailey (1962) dan Rosenthal (1969), berkembangnya ide pemisahan antara pendidikan dan politik di Amerika dilatarbelakangi oleh keinginan para praktisi pendidikan untuk mempertahankan otonomi profesional yang lebih besar bagi mereka, serta untuk melindungi kontinuitas program-program kependidikan mereka dari kepentingan para politikus dan pengaruh proses politik, seperti pemilihan umum.

Para pendukung non-polotical school yang kebanyakan terdiri dari para pelaksana dan praktisi pendidikan dengan sengaja menciptakan seperangkat mitos yang menggambarkan pendidikan sebagai suatu fungsi pemerintahan yang unik, yang harus dikeluarkan dari politik (taken out of poiitics) dan dijaga oleh para pendidik sebagai satu-satunya yang dapat mengamankan kepentingan publik. Roesco Martin, seorang ilmuwan politik lain yang sejalan dengan pandangan Eliot memandang bahwa infiltrasi dalam dunia pendidikan adalah sesuatu yang berbahaya. Menurut Martin (1962: 59-60) "pendidikan publik ... harus dipisahkan (dari politik) dan mendapat perlakuan khusus. Adalah berbahaya bagi sekolah publik apabila dikaitkan dengan sektor publik lainnya, bahwa sekolah tidak ada urusan apa-apa dengan politik pada umumnya, bahwa 
sekolah adalah contoh utama dan kampiun demokrasi". Selama bertahun-tahun doktrin yang dilakukan oleh Martin tersebut diterima secara luas oleh publik Amerika tanpa sikap kritis.

Di Australia, keyakinan bahwa pendidikan dan politik merupakan hal terpisah memang tidak meluas seperti di Amerika, tetapi cukup mengganggu. Perdebatan-perdebatan tentang pendidikan di kalangan politisi, pendidik, atau figur Australia sering membuat kesimpulan yang tak beralasan seperti ungkapan "education is outside politics" (pendidikan berada di luar politik) atau "education should be taken out of politics altogether" (pendidikan harus sepenuhnya keluar dari politik). Ungkapanungkapan tersebut, lanjut Harman (1974: 4), muncul secara alamiah dari mulut sejumlah orang dan kebenarannya jarang dipertanyakan. Selain menghambat pemahaman professional tentang relasi pendidikan dan politik, kata Harman (1974:1), pandangan bahwa politik dan pendidikan merupakan dua hal terpisah juga menghambat penelitian tentang fungsifungsi dan aspek-aspek politik pendidikan. Selain itu, tambahnya lagi, pandangan tersebut juga menimbulkan kebingungan tentang istilah-istilah seperti politik pendidikan (politics of education) dan politik dalam pendidikan (politics in education). Bagi Harman (1980b: 1), pandangan tersebut adalah pendangan tradisional sentimen komunitas yang menatapikan kenyataan behwa sejak awal pendidikan publik di Australia telah terjerembab ke dalam kehidupan politik.

Harman (1974: 4) dalam M. Sirozi (2010: 24) mengidentifikasi empat faktor utama yang memungkinkan munculnya keyakinan, pandangan dan sikap nonpolitical di Australia. Pertama, keyakinan tersebut mungkin bagian dari hasil konflik yang tajam antara gereja dan sekolah pada abad ke-19. Kedua, konflik tersebut memunculkan pandangan yang luas bahwa politik sektarian tidak boleh lagi mengganggu pendidikan, dan bahwa sistem sekolah pemerintah dan penarikan bantuanbantuan dari sekolah-sekolah gereja harus terus berjalan. Ketiga, sistem pendidikan negeri yang sangat tersentralisasi mungkin telah menimbulkan keyakinan yang kuat di kalangan kepala sekolah dan guru-guru. Keyakinan bahwa pendidikan berada di luar politik telah menguat di kalangan pendidi profesional di Australia selama bertahuntahun di bawah pengaruh para pendidik Amerika dan tulisan-tulisan tentang pendidikan Amerika. Keempat, salah satu pandangan populer orang Australia bahwa politik adalah sesuatu yang cenderung kotor dan tidak begitu terhormat karena berkaitan dengan ide tentang korupsi, penyalahgunaan kekuasaan dan kurang baiknya gambaran tentang partai politik. Pandangan ini secara alami dan logis tidak menghendaki politik mengganggu sebuah aktifitas yang berkenaan dengan pembinaan generasi muda.

Namun demikian, menurut Harman (1974: 5) dalam M. Sirozi (2010: 25), pandangan bahwa pendidikan dan politik merupakan dua hal yang sama sekali terpisah, tidak mengandung kebenaran, baik di negara-negara industri seperti di Amerika dan Australia maupun di negara-negara berkembang. Ia percaya bahwa di belahan dunia manapun, "politik dan pendidikan saling terkait dan saling memengaruhi" (1974:5). "Keduanya", lanjut Harman (1974: 5), adalah "dua aktivitas yang mendasar atau fundamental dalam semua masyarakat manusia". Berusaha menemukan jenis masyarakat, apakah modern, demokratik, totaliter, sedang berkembang, atau primitif, dimana pendidikan dan politik tidak terkait dan tidak berinteraksi, tambah Harman (1974: 5), sama sekali adalah suatu usaha sia-sia.

Pendidikan menyangkut proses transmisi ilmu pengetahuan dan budaya, serta perkembangan keterampilan dan pelatihan untuk tenaga kerja dan politik berkenaan dengan praktik kekuasaan, pengaruh dan otoritas, serta berkenaan dengan pembuatan keputusan-keputusan otoritatif tentang alokasi nilai-nilai dan sumberdaya. Karena keduanya syarat dengan proses pengalokasian dan pendistribusian nilai-nilai dalam masyarakat, maka tidaklah sulit untuk memahami bahwa pendidikan dan politik 
adalah dua aktivitas yang akan terus terkait dan saling berinteraksi. Lembaga-lembaga atau agency yang menyelenggarakan aktivitas-aktivitas pada dua sektor kehidupan masyarakat ini akan saling memengaruhi, apapun karakteristik dan budaya yang dimiliki oleh suatu masyarakat. Hal ini terjadi dalam setiap masyarakat, apapun tingkat perkembangannya, sistem politiknya dan ideologinya.

\section{Tantangan Ke Depan}

Saat ini situasi dimana-mana sungguh berbeda. Konsep lama bahwa pendidikan tidak ada kaitan dengan politik (apolitical) sudah dilupakan dan teriakan bahwa pendidikan berada di luar politik sudah tidak terdengar lagi. Perubahan ini terjadi karena terutama karena terus meningkatnya politisasi terhadap pendidikan. Saat ini kebijakan pendidikan telah menjadi tema perdebatan publik dan kompetisi antarpartai politik. Dalam kampanye pemilu legislatif dan pemilu presiden, misalnya, pendidikan menjadi salah satu isu sentral dalam materi kampanye atau dalam rumusan visi dan misi para kandidat. Berbagai isu tentang pendekatan pendidikan sering dipertarungkan di arena publik. Di mana-mana guru-guru telah tampil sebagai kelompok militan yang dengan gigih memperjuangkan hak-hak mereka.

Di Indonesia, Persatuan Guru Republik Indonesia (PGRI) yang selama masa orde baru menjadi "anak manis" penguasa, sekarang cukup kritis terhadap berbagai kebijakan pendidikan, terutama kebijakan yang ada kaitannya dengan nasib dan profesi guru. Di Kampar, aksi politik guru-guru berhasil memaksa mundur Bupati, hanya karena yang bersangkutan melecehkan kedudukan guru. Dalam rangka memperingati Hari Pendidikan Nasional tanggal 2 Mei 2005, guru-guru di berbagai daerah, baik guru tetap maupun guru bantu beramai-ramai turun ke jalan menuntut hakhak mereka, suatu pandangan yang tidak pernah terlihat pada masa Orde Baru.

Perubahan pemahaman tentang hubungan politik dan pendidikan juga dipicu oleh hasil-hasil penelitian yang dilakukan oleh para peminat kajian politik pendidikan. Hasil-hasil tersebut telah turut meyakinkan para profesional pendidikan bahwa berbagai proses dan institusi pendidikan bersifat politik. Saat ini kita menyaksikan pengakuan yang luas di kalangan guru, administratur pendidikan, dan di kalangan masyarakat luas, bahwa tekanan-tekanan dan kekuatan politik sangat berpengaruh terhadap institusi dan kebijakan pendidikan. Harman (1980: 3) melukiskan situasi tersebut dalam kalimat pendek: "education is certainly not outside politics" (pendidikan sungguh tidak berada di luar politik). Obsesi kita tentang sistem pendidikan yang steril dari politik boleh saja mendorong kita untuk percaya atau berpikir bahwa tidak ada hubungan antara pendidikan dan politik. Namun, realitas yang kita lihat dan kita hadapi dimana-mana secara jelas memperlihatkan bahwa pendidikan dan politik senantiasa berkelindan; saling memengaruhi, saling mengisi dan saling mewarnai.

Untuk dapat memahami berbagai persoalan pendidikan yang ada di tengah masyarakat tidak hanya diperlukan dasar pengalaman dan pengetahuan pendidikan, tetapi juga diperlukan pengetahuan tentang aspek-aspek dan konteks politik dari persoalan-persoalan kependidikan tersebut.

\section{Daftar Pustaka}

Anonim (2005). Standar Nasional Pendidikan. Jakarta: Cemerlang.

Riant Nugroho (2008). Pendidikan Indonesia: Harapan, Visi,dan Strategi, Jogjakarta: Pustaka Pelajar.

Sirozi, M., (2010). Politik Pendidikan, Dinamika Hubungan Antara Kepentingan Kekuasaan dan Praktek Penyelenggaraan Pendidikan. Jakarta: PT Raja Grafindo Persada.

Tilaar , H.A.R. \& Riant Nugroho (2008). Kebijakan Pendidikan, Pengantar untuk Memahami Kebijakan Pendidikan dan Kebijakan Pndidikan Sebagai Kebijakan Publik. Yogyakarta: Pustaka Pelajar. 
(2003). Kekuasaan dan Pendidikan:

Suatu Tinjauan dari Perspektif Studi

Kultural. Magelang: Indonesia Tera. 